\title{
Eugène Gley (1857-1930).
}

EUĠ̀NE GLEY, who died on 24th October 1930, was born in 1857 at Épinal, where his father, Gérald Gley, was Professor of Latin. Gérald Gley came from Gérardmer in the Vosges: the name Gley is said to indicate a Celtic origin. Eugène Gley began to study medicine at Montpellier but transferred to Nancy, where he obtained the doctorate in 1881. Probably he had already determined to pursue Physiology, for his thesis was on a physiological subject: "Étude expérimentale sur l'état du pouls carotidien pendant le travail intellectuel "; the gist of it was published in the same year in the Archives de physiologie normale et pathologique. At the age of 23 he proceeded to Paris. Here he at first worked with Marey, whom he was a few years later to eulogise in an allocution pronounced on behalf of the Société de Biologie on the occasion of the presentation to Marey of a medal commemorative of the completion of his fiftieth year of scientific work. In 1883 Gley was made "préparateur des travaux pratiques de physiologie" in the Faculty of Medicine, and in 1889 became "professeur agrégé." In 1893 he was appointed to the Muséum d'Histoire Naturelle, where he continued actively to pursue physiological researches. His reputation as an experimental physiologist was now established: he had already published more than 130 papers dealing with different aspects of the subject. During the next few years he continued to produce an astonishing amount of work both alone and in collaboration with others. Included amongst these are many distinguished names-Richet, Lapicque, Charrin, Phisalix, Thiroloix, Pachon, Langlois. As there was no vacant professorship in Physiology in Paris, the Collège de France created in 1908 a Chair of General Biology which he was invited to occupy and which he retained until his death.

The most striking feature of Gley's scientific life is its activity. There were few subjects in Physiology which were not included in his investigations, and these continued without intermission during fifty years. A list of his publications from 1881 to 1929 embraces 524 titles!* His work is characterised by accuracy of observation and clarity of exposition; to which must be added a critical restraint in the premature formulation of conclusions which is a somewhat rare feature in scientific literature.

Considering the number of subjects he dealt with and the masterly

* "Liste chronologique des travaux et écrits scientifiques de Eugène Gley"-Arch. inter. de pharmacodyn. et de thér., xxxviii, 1928. 
manner in which they are treated, it is a little difficult to select those upon which his reputation is mainly based. But on the whole one would be inclined to pick out his work on the internal secretions as the most important. 'This began with observations on the results of removal of the thyroid and parathyroid, was continued on the effects of extracts of these and other endocrine glands, and culminated in a series of important experimental observations on the secretion of adrenaline, most of these last having been carried out with the collaboration of A. Quinquaud. A still more recent series of observations on the internal secretion of the sex-glands, undertaken with the co-operation of pupils and colleagues (Pézard, Caridroit, Champy), have served materially to advance our knowledge regarding this important branch of endocrinology.

In an early investigation, carried out in collaboration with L. Camus upon the serum of the eel (which Mosso had found to be highly toxic for other animals), Gley was able to show that the toxicity could be antagonised by the administration of very small doses gradually increased, enabling the cells of the organism to produce an antitoxin which prevents the otherwise toxic effects of the serum. In the course of this research the effect of hæmolysins upon the blood-corpuscles was also studied. It was found that this also could be antagonised by vaccinating an animal with minute doses of hæmolysin, thereby causing the production of antihæmolysins. These experiments helped materially to place upon a physiological basis the doctrine of the production of immunity by antibodies. Other subjects of Gley's researches were the coagulation of blood-plasma, the anticoagulant action of peptones and of the liver, the character of sensations, especially that of taste, the relation of the nervous system to secretion, the action of drugs, especially those acting upon the heart and blood-vessels, the production of anaphylaxis and of tachyphylaxis, the external and internal secretions of the pancreas, the pathogeny of goitre, the presence of a "vagal" substance in blood, and the influence of calcium on nerve excitability.

It is not infrequently found that scientific observers, having once worked at and apparently exhausted a subject, dismiss it from their future programme. But on looking through the chronological list of Gley's works we find him again and again reverting to subjects previously investigated, with the view of throwing further light on points which, in his judgment, he had incompletely elucidated.

Gley's books, as distinguished from his scientific articles and his memorial and other discourses, were not numerous, the principal being the Traité élémentaire de physiologie, published in 1906-1909 in three parts, 
and in subsequent editions appearing in one volume, the 7 th and last in 1928; Les sécrétions internes, a small eminently readable work which first appeared in 1914, passed through two or three editions and has been translated into several languages; and another small book, Les grands problèmes de l'endocrinologie, which appeared in 1926 and is distinguished by the same breadth of view that characterises his other publications.

A fluent speaker and a notable orator, Gley was frequently selected to deliver allocutions and eulogies on behalf of the Collège de France, or the Académie de Médecine-of which he occupied at one time the Presidential Chair-or the Société de Biologie, of which for some years he was secretaire general. The list of his writings includes, therefore, many discourses pronounced at the obsequies or centenaries of eminent biologists or at the jubilee celebrations of distinguished physiologists. No one will easily forget the brilliancy and fervour of his eloquence on such occasions. To British physiologists he was persona grata, and they on the other hand were sure of a warm welcome from him both in his laboratory and in his hospitable home. A prominent figure at all the International Congresses of Physiology, he was long the representative of French physiology on the International Committee. He was a frequent visitor to this country, and made a point of being present in London at the dinner in celebration of the fiftieth anniversary of the Physiological Society. We little thought that his memorable speech on that occasion was to be the last we should have an opportunity of hearing. The sincerity of his character and the charm of his personality endeared him to his friends, who will long retain a pleasant memory both of himself and of his gracious consort, whose death in 1923 he had to deplore. He leaves behind him a son (Pierre) who, after having obtained distinction in the War, is now following in his distinguished father's footsteps, having already been the author of more than one paper of special physiological interest.

Eugène Gley was elected an Honorary Fellow of the Society in 1916.

E. A. S.-S. 